\title{
Sperm transport and elimination from the mare's reproductive tract
}

\author{
Mats H. T. Troedsson
}

Maxwell H. Gluck Equine Research Center, Department of Veterinary Science, University of Kentucky, Lexington

\begin{abstract}
Summary
Transportation of viable spermatozoa to the oviduct is a rapid process that is completed within 4 hours of breeding. Uterine contractions play a major role in this process, but other mechanisms such as sperm motility, epithelial cilia and a possible effect of seminal PGE on the utero-tubal junction may also be involved. Only a small portion of inseminated or ejaculated semen reach the oviduct. The majority of spermatozoa needs to be effectively eliminated from the uterus before the embryo descends down from the oviduct to the uterine lumen approximately 5 days after fertilization. Myometrial contractions and semen-induced inflammation are responsible for this process. Recent data suggest that sperm elimination from the uterus is a selective process, targeting dead spermatozoa, while viable spermatozoa are protected from PMN-binding and phagocytosis by a specific seminal plasma protein.
\end{abstract}

Keywords: horse, reproduction, sperm transport, endometritis, semen, uterus

\begin{abstract}
Spermientransport und -elimination im Reproduktionstrakt der Stute
Der Transport lebensfähiger Spermatozoen zum Eileiter ist ein sehr schneller Vorgang, der innerhalb von 4 Stunden nach der Bedeckung abgeschlossen ist. Dafür sind hauptsächlich die uterinen Kontraktionen verantwortlich, jedoch spielen auch andere Mechanismen wie Motilität der Spermien, epitheliale Zilien und ein möglicher Effekt seminalen PGE's auf die utero-tubale Verbindung eine Rolle. Lediglich ein kleiner Anteil des inseminierten bzw. ejakulierten Spermas erreicht den Eileiter. Der Hauptanteil der Spermien muss effektiv aus dem Uterus eliminiert werden, bevor der Embryo vom Eileiter in den Uterus ungefähr am fünften Tag nach der Befruchtung herabgewandert ist. Für die Elimination sind myometriale Kontraktionen und eine spermainduzierte Entzündung verantwortlich. Neveste Forschungsergebnisse sprechen dafür, dass die Spermienelimination ein selektiver Prozess ist und gezielt tote Spermatozoen betrifft, während lebensfähige Spermatozoen durch ein spezifisches Seminalplasmaprotein vor einer PMN-Bindung und Phagozytose geschütz† sind.
\end{abstract}

Schlüsselwörter: Pferd, Reproduktion, Spermientransport, Endometritis, Samen, Uterus

\section{Introduction}

Semen is deposited into the equine uterus during both natural breeding and artificial insemination. As a result of the stallion ejaculating into the uterine lumen, rather than into the vagina, natural breeding in horses often results in bacterial contamination of the uterus. Following deposition into the uterine lumen, spermatozoa are transported to the oviduct by a combination of uterine motility, sperm motility, and epithelial cilia activity. Only $<1 \%$ of inseminated spermatozoa are successfully transported to the site of fertilization in the oviducts (Scott et al. 1995, Bader and Krause 1980). The low yield of spermatozoa in the oviduct from an insemination dose is further decreased after insemination with frozen/ thawed semen (Bader and Krause 1980).

Since only a small portion of the inseminated or ejaculated semen is transported to the oviduct, most of the ejaculated spermatozoa, together with seminal plasma and contaminating bacteria have to be effectively eliminated from the uterus shortly after the completion of sperm transport to the oviduct. Uterine contractions are involved in this process, but the innate immune system also plays an important role in the elimination of sperm and bacteria from the uterus (Bader and Krause 1980, Troedsson et al. 1995b, Troedsson 1999, Katila et al. 2000). The objective of this review is to summarize our current understanding on the transport of viable spermatozoa to the oviduct, and the timely elimination of excess spermatozoa and bacteria from the uterus.

\section{Sperm transport}

Increased myometrial contractions associated with breeding appears to be an important component of sperm transport to the oviducts (Katila et al. 2000) and is also responsible for rapid sperm elimination from the uterus through the cervix. Two phases of myoelectrical activity has been observed following insemination (Troedsson et al. 1998). An immediate period of myometrial contractions of short duration, followed by a later phase of contractions of several hours duration was recorded in response to insemination (Figure 1). The mechanism of myometrial response to insemination was not determined. However, the first phase of myometrial contractions coincided with stimulation of the vagina and the cervix, with a possible release through the Ferguson reflex. Furthermore, the introduction of semen into the uterine lumen may affect the myometrium through seminal estrogen and prostaglandins. Oxytocin is released from the pituitary gland in response to physical contact with a stallion, as well as stimulation of the vagina and the cervix during artificial insemination (Alexander et al. 1995, Madill et al. 2000). These stimuli also induce myometrial contrac- 
tions, as measured by electromyography (Taverne et al. 1979, Troedsson et al. 1998, Madill et al. 2000).

A rapid transport of a small number of spermatozoa through the female tract into the peritoneal cavity following mating has been described in several species, but not equines (Phillips and Andrews 1937, VanDenmark and Moeller 1951, Overstreet and Cooper 1978). The time for equine spermatozoa to reach the oviduct following breeding is apparently still relatively short. Spermatozoa have been identified in the oviduct within 0.5 - 1 hour after insemination, and sperm transport is thought to be completed within 4 hours after breeding (Bader 1982, Brinsko et al. 1990, Brinsko et al. 1991, Scott et al. 1995, Scott et al. 2002, Fiala et al. 2008). Interestingly, spermatozoa have been found in uterine glands 1 hour after insemination (Fiala et al. 2008). The authors suggested that the uterine glands may serve as an additional sperm reservoir besides the oviductal isthmus and the uterotubal junction (Thomas et al. 1994, Scott et al. 2002). In addition to its role as a preovulatory sperm reservoir, the utero-tubal junction serves as a major barrier for spermatozoa to reach the oviduct. It is not clear if transport through the equine utero-tubal junction is passive, or if it involves a selection for normal and motile spermatozoa. A greater fraction of morphological, motile sperm was found in the oviduct when mares were bred to a fertile stallion, compared to mares bred to subfertile stallions (Scott et al. 1995). However, this may have been the result of superior binding of normal spermatozoa to the oviductal epithelium, rather than a failure of abnormal sperm to cross the utero-tubal junction (Thomas and Ball 1996). Prostaglandin E (PGE) plays a role in the transport of embryos through the oviduct, and it was hypothesized that seminal PGE also may be responsible for transport of spermatozoa across the oviduct (Troedsson et al. 2005). The authors observed a greater number of spermatozoa in the oviduct following hysterendoscopic insemination of $24 \times 10^{6}$ spermatozoa if the inseminate contained $2 \mathrm{ng} / \mathrm{mL}$ of PGE2, compared to inseminations without PGE2. The concentration of PGE2 in the inseminate was based on measurement of PGE2 in semen from stallions with normal fertility. However, the number of mares participating in the study was small, and the results should be interpreted with caution.

Binding of spermatozoa to oviductal epithelial cells appears to extend their viability (Ellington et al. 1993, Thomas and Ball 1996), and intracellular calcium concentrations were maintained at basal levels in spermatozoa attached to the oviduct, preventing them from undergoing capacitation (Dobrinski et al. 1996). Cryopreservation of equine semen alters the ability of spermatozoa to bind to the oviductal epithelium in vitro, and the ability of frozen/thawed to reach the oviduct may also be impaired (Dobrinski et al. 1995, Bader and Krause 1980). This may explain clinical observations that frozen/thawed semen needs to be inseminated very close to ovulation, while fresh semen maintain fertility for days in the mare's reproductive tract.

\section{Sperm elimination}

Increased myometrial contraction is responsible for elimination of excess spermatozoa and contaminating bacteria from the uterus through the cervix. However, not all excess sper- matozoa are removed through this mechanism. Semen induces an inflammatory reaction in the uterine lumen (Kotilainen et al. 1994, Katila 1995, Troedsson et al. 1995b, Troedsson et al. 1995a, Troedsson et al. 2002). This mechanism involves a cascade of inflammatory reactions. In vitro studies suggest that when equine spermatozoa enter the uterus, they activate complement in uterine secretion (Troedsson et al. 1995b, Troedsson et al. 2002), resulting in an influx of PMNs into the uterine lumen. Activated PMNs bind to spermatozoa in the presence of complement factor C3b, and a complement independent mechanisms (Dahms and Troedsson 2002). The nature of this binding is unknown, but observations suggest that it is mediated by both the extrusion of DNA from PMNs forming extracellular neutrophil traps (NET), and a traditional ligand receptor binding (Brinkmann et al. 2004; Alghamdi and Foster 2005). Following binding, the spermatozoa are phagocytosed by the PMNs. During the activation of PMNs, prostaglandin F2 $\alpha$ (PGF2 $\alpha$ ) is released from the cell membrane by the metabolism of arachidonic acid via the cycloxygenase pathway. In addition to being an inflammatory mediator, PGF2 $\alpha$ causes contraction of smooth muscle, including the myometrium (Troedsson et al. 1995c). There is a temporal association between the breeding-induced inflammation, and the second phase of increased myoelectrical activity that is observed after insemination (Figure 1).

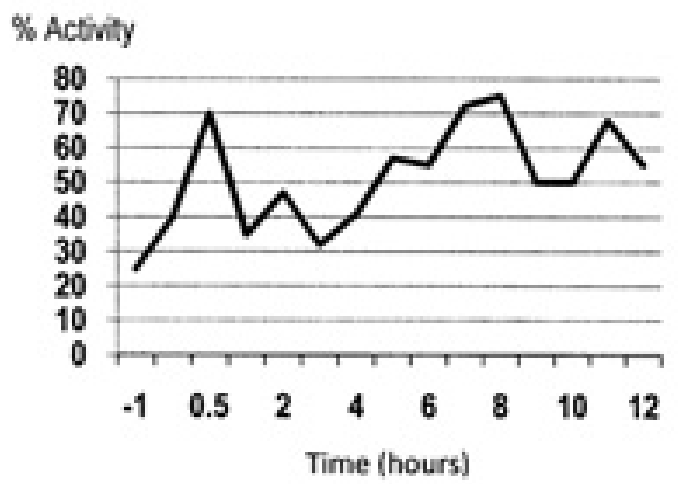

Fig. 1 Total myoelectrical activity (\% of time activity was recorded) following insemination of a mare. Insemination resulted in an immediate increase in myoelectrical activity that lasted for 0.5 hours. Following return to baseline, myoelectrical activity increased in a second phase that started 4 hours after insemination and lasted for more than 8 hours. (Adapted from Troedsson et al, 1998).

Totale myoelektrische Aktivität (gemessene Prozent der Zeitaktivität) nach Insemination einer Stute. Nach der Insemination erfolgt ein sofortiger Anstieg der myoelektrischen Aktivität, die über eine halbe Stunde anhält. Nach einem Rückgang auf die Basiswerte, steigt die myoelektrische Aktivität in einer zweiten Phase an. Diese beginnt vier Stunden nach Insemination und bleibt für mehr als acht Stunden bestehen. (aus Troedsson et al. 1998).

Uterine contractions are believed to physically remove accumulated fluid, and harmful inflammatory products from the uterus. Once these products are removed from the uterine lumen, the inflammation subsides, and the uterine environment returns to its normal state. Breeding-induced uterine inflammation is a physiological reaction to semen, and it appears to be a normal process by which sperm is eliminated from the mares' reproductive tract. A failure of the uterine defense mechanisms to effectively eliminate an antigen and inflammatory products from the uterus results in persistent endometritis. In approximately $15 \%$ of brood mares the system fails and the initial physio- 
logical inflammation becomes a pathological problem, with a detrimental effect on fertility (Pycock and Newcombe 1996, Rasch et al. 1996, Zent and Troedsson 1998). It is currently believed that a failure of mechanical aspects of the uterine defense system is the major contributor in uterine clearance of bacteria and inflammatory products.

There is accumulating evidence that seminal plasma plays a key role in the modulation of breeding-induced endometritis (Troedsson et al. 2000, Alghamdi et al. 2004, Troedsson et al. 2005, Fiala et al. 2002, Troedsson 2006). Seminal plasma contains proteins, enzymes, and hormones (such as prostaglandins and estrogens). In vitro, it has been shown to suppress complement activation, PMN-chemotaxis, and phagocytosis (Dahms and Troedsson 2002, Troedsson et al. 2000). The duration of a breeding-induced uterine inflammation was shown to be shorter when seminal plasma was included in an insemination dose, compared to its removal and replacement by a commercial semen extender (Troedsson et al. 2002). This finding was of clinical importance, since an inflammatory response to semen may interfere with normal development and viability of an embryo if not resolved in a timely manner. Seminal plasma also functions in breeding-induced endometritis to protect spermatozoa from being phagocytosed and destroyed in an inflammatory environment (Alghamdi et al. 2004). This finding was somewhat surprising, since an important role of the breeding-induced inflammation is to remove spermatozoa from the uterus by PMN-phagocytosis (Troedsson et al. 1995a, Troedsson 1999). However, because PMNs are present within 0.5 hours after breeding while sperm transport is completed by four hours after breeding, fertile spermatozoa needs to reach the oviduct in the presence of a uterine inflammation. In addition, spermatozoa are deposited into an inflammatory environment when mares are bred twice within 12 to 24 hours. Recent data supports a system that protects viable spermatozoa from being phagocytosed while the uterus is able to maintain an effective sperm elimination of non-viable spermatozoa (Troedsson et al. 2006). The authors found that specific proteins in seminal plasma protect viable spermatozoa from binding to $\mathrm{PMNs}$, and promote binding and phagocytosis of dead and damaged spermatozoa. The observation suggests that transport of spermatozoa through the uterus is selective for viable spermatozoa, and may explain why a greater fraction of morphological, motile sperm was found in the oviduct when mares were bred to a fertile stallion, compared to when mares were bred to subfertile stallions (Scott et al. 1995).

In conclusion, sperm transport and elimination from the uterus involve a fine-tuned system of uterine contractions and multiple facets of the innate immune system. Both transport and elimination of sperm appear to be selective for different populations of spermatozoa within an ejaculate.

\section{References}

Alexander S. L., Irvine C. G. H., Shand N. and Evans M. J. (1995) Is luteinizing hormone secretion modulated by endogenous oxytocin in the mare? Studies on the role of oxytocin and factors affecting its secretion in estrous mares. Equine Reprod. VI, 361-371

Alghamdi A. S. and Foster D. N. (2005) Seminal DNase frees spermatozoa entangled in neutrophil extracellular traps. Biol. Reprod. 73:1174-1181
Alghamdi A. S., Foster D. N. and Troedsson M. H. (2004) Equine seminal plasma reduces sperm binding to polymorphonuclear neutrophils (PMNs) and improves the fertility of fresh semen inseminated into inflamed uteri. Reproduction. 127, 593-600

Bader H. (1982): An investigation of sperm migration into the oviducts of the mare. J Reprod Fertil Suppl. 32, 59-64

Bader H. and Krause A. (1980) Investigations about the transport, distribution and the fate of spermatozoa in the genital tract of the mare. 9th International Congress on Animal Reproduction and Artificial Insemination, Madrid, Spain, 197-205

Brinkmann V., Reichard U., Goosmann C, Fauler B., Uhlemann Y., Weiss D. S., Weinrauch Y. and Zychlinsky A. (2004) Neutrophil extracellular traps kill bacteria. Science 303, 1532-1535

Brinsko S. P, Varner D. D. and Blanchard T. L. (1991) The effect of uterine lavage performed four hours post-insemination on pregnancy rates in mares. Theriogenology 35, 1111-1119

Brinsko S. P., Varner D. D., Blanchard T. L. and Meyers S. A. (1990) The effect of postbreeding uterine lavage on pregnancy rate in mares. Theriogenology 33, 465-475

Dahms B. J. and Troedsson M. H. T. (2002) The effect of seminal plasma components on opsonisation and PMN-phagocytosis of equine spermatozoa. Theriogenology 58, 457-460

Dobrinski I., Suarez S. S. and Ball B. A. (1996) Intracellular calcium concentration in equine spermatozoa attached to oviductal epithelial cells in vitro. Biol. Reprod. 54, 783-788

Dobrinski I., Thomas P. G. and Ball B. A. (1995) Cryopreservation reduces the ability of equine spermatozoa to attach to oviductal epithelial cells and zonae pellucidae in vitro. J. Androl. 16, 536542

Ellington J. E., Ball B. A., Blue B. J. and Wilker C. E. (1993) Capacitation-like membrane changes and prolonged viability in vitro of equine spermatozoa cultured with uterine tube epithelial cells. Am. J. Vet. Res. 54, 1505-1510

Fiala S. M., Jobim M. I. M., Katila T., Gregory R. M. and Mattos R. C. (2008) Sperm distribution in the oviduct and uterus of mares within two hours after artificial insemination. Pferdeheilkunde. 24 96-98.

Fiala S. M., Pimentel C. A., Steiger K., Mattos A. L. G., Gregory R. M. and Mattos R. C. (2002) Effect of skim milk and seminal plasma uterine infusions in mares. Theriogenology 58, 491-494

Katila T. (1995) Onset and duration of uterine inflammatory response of mares after insemination with fresh semen. Equine Reproduction VI, 515-517

Katila T., Sankari S. and Makela O. (2000) Transport of spermatozoa in the reproductive tracts of mares. J. Reprod. Fertil. Suppl. 56, $571-578$

Kotilainen T., Huhtinen M. and Katila T. (1994) Sperm-induced leukocytosis in the equine uterus. Theriogenology 41, 629-636

Madill S., Troedsson M. H. T., Alexander S. L., Shand N., Santschi E. M. and Irvine C. H. G. (2000) Simultaneous recording of pituitary oxytocin secretion and myometrial activity in oestrous mares exposed to various breeding stimuli. J. Reprod. Fertil. Suppl. 56, 351-361

Overstreet J. W. and Cooper G. W. (1978) Sperm transport in the reproductive tract of the female rabbit: I. The rapid transit phase of transport. Biol. Reprod. 19, 101-114

Phillips R. W. and Andrews F. N. (1937) The speed of travel of ram spermatozoa. Anat. Record 68, 127-132

Pycock J. F. and Newcombe J. R. (1996) The relationship between intraluminal uterine fluid, endometritis, and pregnancy rate in the mare. Equine Pract. 18, 19-22

Rasch K., Schoon H. A., Sieme H. and Klug E. (1996) Histomorphological endometrial status and influence of oxytocin on the uterine drainage and pregnancy rate in mares. Equine Vet. J. 28, 455460

Scott M. A., Liu I. K. M. and Overstreet J. W. (1995) Sperm transport to the oviducts: Abnormalities and their clinical implications. Proceedings of the Annual Convention of the American Association of Equine Practitioners, 1-2

Scott M. A., Varner D. D., Liu I. K. M. and Enders A. C. (2002) Presumptive evidence of a preovulatory sperm reservoir in the mare: morphological investigations using scanning electron microscopy. Theriogenology 58, 639-642 
Taverne M. A., van der Weyden G. C., Fontijne P., Dieleman S. J., Pashen R. L. and Allen W. R. (1979) In-vivo myometrial electrical activity in the cyclic mare. J. Reprod. Fertil. 56, 521-532

Thomas P. G. and Ball B. A. (1996) Cytofluorescent assay to quantify adhesion of equine spermatozoa to oviduct epithelial cells in vitro. Mol. Reprod. Dev. 43, 55-61

Thomas P. G., Ball B. A., Miller P. G., Brinsko S. P. and Southwood L. (1994) A subpopulation of morphologically normal, motile spermatozoa attach to equine oviductal epithelial cell monolayers. Biol. Reprod. 51, 303-309

Troedsson M. H. (1999) Uterine clearance and resistance to persistent endometritis in the mare. Theriogenology 52, 461-471

Troedsson M. H. (2006) Breeding-induced endometritis in mares. Vet. Clin. North Am. Equine Pract. 22, 705-712

Troedsson M. H., Desvousges A., Alghamdi A. S., Dahms B., Dow C. A., Hayna J., Valesco R., Collahan P. T., Macpherson M. L., Pozor M. and Buhi W. C. (2005) Components in seminal plasma regulating sperm transport and elimination. Anim. Reprod. Sci. 89, 171-186

Troedsson M. H., Liu I. K. and Crabo B. G. (1998) Sperm transport and survival in the mare: a review. Theriogenology 50, 807-818

Troedsson M. H. T., Alghamdi A. S. and Mattisen J. (2002) Equine seminal plasma protects fertility of spermatozoa in an inflamed uterine environment. Theriogenology 58, 453-456

Troedsson M. H. T., Crabo B. G., Ibrahim N., Scott M. and Ing M. (1995) Mating-induced endometritis: mechanisms, clinical importance and consequences. Proceedings of the Annual Convention of the American Association of Equine Practitioners, 11-12
Troedsson M. H. T., Desvousges A. L., Hansen P. J. and Buhi W. C. (2006) Equine seminal plasma proteins protect live spermatozoa from PMN-binding and phagocytosis, while providing a mechanism for selective sperm elimination, of apoptotic and dead spermatozoa. Anim. Reprod. Sci. 9460-61

Troedsson M. H. T., Lee C. S., Franklin R. D. and Crabo B. G. (2000) The role of seminal plasma in post-breeding uterine inflammation. Journal of Reproduction and Fertility Supplement. 56, 341-349

Troedsson M. H. T., Steiger B. N., Ibrahim N. M., Foster D. N. and Crabo B. G. (1995b) Mechanisms of sperm induced endometritis in the mare. Biol. Reprod. 52, 307 (abstract)

VanDenmark N. L. and Moeller A. N. (1951) Speed of spermatozoa transport in reproductive tract of estrous cow. Am. J. Physiol. 165, 674-679

Zent W. W. and Troedsson M. H. T. (1998) Postbreeding uterine fluid accumulation in a normal population of Thoroughbred mares: a field study. Proceedings of the Annual Convention of the American Association of Equine Practitioners, 64-65

Mats H. T. Troedsson

Maxwell H. Gluck Equine Research Center

Department of Veterinary Science

University of Kentucky

Lexington, KY 40546-0099 (USA)

M.Troedsson@uky.edu 